\title{
HUBUNGAN PENGETAHUAN KELUARGA TENTANG BPJS (BADAN PENYELENGGARA JAMINAN SOSIAL) DENGAN PERILAKU KELUARGA DALAM MENGIKUTI PROGRAM BPJS
}

\author{
Indah Rohmawati \\ Prodi DIII Keperawatan STIKes Hutama Abdi Husada Tulungagung \\ Email:rohmawatiindah2@gmail.com
}

\begin{abstract}
Everyone is entitled to an adequate standard of living for the health and well-being of himself and his family including the right to food, clothing, housing and health care. In addition, everyone also has the obligation to participate in social health insurance program through BPJS (Social Security Administering Body). Although the government regulation has been set still still find a family that has not become a participant BPJS Health. Many factors that can influence the behavior in following the BPJS program include knowledge of BPJS. The purpose of the research is to prove the relationship of family knowledge about BPJS (Social Security Administering Body) with family behavior in following BPJS program.

Type of analytic research with cross sectional design and conducted for 1 year. Population All families in RT 001 RW 001 Tenggarejo Village Tanggunggunung District Tulungagung Regency, with total sampling technique obtained 78 respondents. Data were collected by using a knowledge questionnaire about BPJS and behavioral questionnaires in the BPJS program. Data analysis technique using Chi-Square test and got the result $p$ value of 0.009 means there is a relationship between the knowledge of respondents about BPJS with respondents' behavior in following the BPJS program, this is because the lack of knowledge about BPJS can cause not have a solid basis to create new behavior and tend not to follow the new behavior or in this case do not follow BPJS program
\end{abstract}

Keywords: Knowledge, Behavior, BPJS

\section{PENDAHULUAN}

Setiap orang berhak atas derajat hidup yang memadai untuk kesehatan dan kesehjahteraan dirinya dan keluarganya termasuk hak atas pangan, pakaian, perumahan dan perawatan kesehatan. Berdasarkan hal tersebut beberapa negara mengambil inisiatif untuk mengembangkan jaminan sosial antara lain jaminan kesehatan bagi semua penduduk (Universal Health Coverage). Di Indonesia untuk mendukung kegiatan tersebut membuat beberapa kebijakan antara lain dalam UU NO.36/2009 pasal 5 ayat (2) ditegaskan bahwa setiap orang perlu hak yang sama dalam memperoleh akses atas sumber daya di bidang kesehatan dan memperoleh pelayanan kesehatan yang aman, bermutu, dan terjangkau. Selain itu, Setiap orang juga mempunyai kewajiban turut serta dalam progam jaminan kesehatan sosial melalui BPJS (Badan Penyelenggara Jaminan sosial). UU NO.40/2004 pasal 1 mengamanatkan bahwa jaminan sosial wajib bagi seluruh penduduk termasuk Jaminan Kesehatan Nasional (JKN) melalui BPJS. Walaupun peraturan pemerintah tersebut telah di tetapkan masih saja di temukan keluarga yang belum menjadi peserta BPJS Kesehatan .

Berdasarkan data yang di peroleh dari Departemen kesehatan RI tahun 2011 peserta Jamkesmas mencapai $32.37 \%$, Askes PNS dan TNI POLRI $7.29 \%$, Jamkesda $13.98 \%$, Jamsostek $2.36 \%$, Jamkes oleh perusahaan $6.51 \%$, Asuransi Swasta dan lain-lain 2.48\% dan yang belum mempunyai jaminan Kesehatan mencapai 35.12\%. 
Berdasarakan tujuh daerah di wilayah BPJS Kediri yaitu Kabupaten Kediri, Kabupaten Blitar, Kabupaten Tulungagung, Trenggalek, dan Nganjuk, yang sudah menjadi peserta BPJS Kesehatan mencapai 2,6 juta jiwa sekitar $40 \%$ saja. Berdasarkan pengalaman dari peneliti di rumah sakit dr.Iskak Tulungagung masih banyak di jumpai pasien yang belum mendaftar BPJS Kesehatan sehingga keluarga yang mau mendaftarakan pasien, menjadi bingung karena pendafatarannya terkesan sangat rumit di tambah lagi kartu BPJS Kesehatan baru aktif setelah 14 hari dari pendafataran. Sedangkan berdasarkan study pedahuluan yang di lakukan peneliti pada tanggal 24 oktober 2014 di RT 001 RW 001 desa Tenggarejo Kecamatan Tanggunggunung Kabupaten Tulungagung dari jumlah penduduk 2297 jiwa yang menjadi peserta BPJS Kesehatan sebesar 465 jiwa sekitar $19,85 \%$ dari jumlah penduduk.

Masih ditemukannya masyarakat yang belum terdaftar menjadi peserta BPJS Kesehatan akan berdampak pada pelayanan kesehatan yang terkesan sangat mahal sehingga akses untuk mendapatkan pelayanan kesehatan yang aman dan bermutu menjadi kurang. Mengingat bahwa kesehatan sangat penting bagi kehidupan dan jaminan kesehatan sangat di perlukan bagi masyarakat maka solusi untuk mengatasi permasalahan di atas yaitu dengan cara mengetahui dan merubah faktor faktor yang mempengaruhi perilaku masyarakat dalam mengikuti program BPJS Kesehatan salah satunya yaitu pengetahuan keluarga tentang BPJS Kesehatan. Terkait dengan hal tersebut di atas maka peneliti tertarik untuk meneliti " Hubungan pengetahuan keluarga tentang BPJS (badan penyelenggara jaminan sosial) dengan perilaku keluarga dalam mengikuti program BPJS".

\section{METODE PENELITIAN}

Jenis Penelitian

Penelitian analitik dengan desain cross sectional

\section{Metode Pengumpulan Data}

Pengumpulan data dengan menggunakan pengumpulan data secara primer.

\section{Instrument Penelitian}

Instrument penelitian menggunakan instrumen tertutup untuk mengukur pengetahuan tentang BPJS dan keikutsertaan dalam program BPJS

\section{Populasi Penelitian}

Seluruh keluarga di RT 001 RW 001 desa Tenggarejo Kecamatan Tanggunggunung Kabupaten Tulungagung.

\section{Prosedur Sampel}

Tehnik sampling yang digunakan adalah total sampling, pada seluruh kepala keluarga yang ada di RT 001 RW 001 desa Tenggarejo Kecamatan Tanggunggunung Kabupaten Tulungagung. Jumlah sampel 78 responden

Tehnik Pengumpulan Data dan Analisa

Data

\section{Pengumpulan data}

1. Sebelum melakukan penelitian, peneliti terlebih dahulu mengajukan izin ke STIKes Hutama Abdi Husada Tulungagung.

2. Responden yang setuju menandatangani persetujuan menjadi responden atau informed consent dan mengisi kuesioner pengetahuan tentang BPJS dan keikutsertaan dalam program BPJS

\section{Analisis data}

Analisa data yang menggunakan tahapan univariat dan bivariat. Karakteristik data sampel data katagorikal didiskripikan dalam $\mathrm{n}$ dan persentase (\%). Untuk menentukan apakah ada hubungan antara 2 variabel diuji secara statistik dengan uji Chi-Square

HASIL DAN PEMBAHASAN

Hasil penelitian

Karakteristik Subyek Penelitian Deskripsi mengenai karakteristik 
responden menggunakan analisis univariate. Analisis univariate ini bertujuan untuk mengetahui jumlah dan persentase dari karakteristik responden. Berikut adalah data mengenai karakteristik responden yang menjadi subyek penelitian

Tabel 5.1 Karakteristik Responden Penelitian

\begin{tabular}{|c|c|c|}
\hline Umur & $\begin{array}{c}\text { Jumlah } \\
\text { (n) }\end{array}$ & $\begin{array}{c}\text { Persentase } \\
(\%)\end{array}$ \\
\hline 21-40 Tahun & 22 & 28.2 \\
\hline 41-60 Tahun & 40 & 51.3 \\
\hline$>60$ Tahun & 16 & 20.5 \\
\hline Jumlah & 78 & 100 \\
\hline Pekerjaan & $\begin{array}{c}\text { Jumlah } \\
\text { (n) }\end{array}$ & $\begin{array}{c}\text { Persentase } \\
(\%)\end{array}$ \\
\hline Petani & 42 & 53.8 \\
\hline Wiraswasta & 29 & 37.2 \\
\hline PNS & 7 & 9.0 \\
\hline Jumlah & 78 & 100.0 \\
\hline Pendidikan & $\begin{array}{c}\text { Jumlah } \\
\text { (n) }\end{array}$ & $\begin{array}{c}\text { Persentase } \\
(\%)\end{array}$ \\
\hline SD & 36 & 46.2 \\
\hline SMP & 29 & 37.2 \\
\hline SMA & 6 & 7.7 \\
\hline PT & 7 & 9.0 \\
\hline Jumlah & 78 & 100.0 \\
\hline Penghasilan & $\begin{array}{c}\text { Jumlah } \\
\text { (n) }\end{array}$ & $\begin{array}{c}\text { Persentase } \\
(\%)\end{array}$ \\
\hline$<1$ juta & 44 & 56.4 \\
\hline 1-2 juta & 28 & 35.9 \\
\hline 3-5 juta & 6 & 7.7 \\
\hline Jumlah & 78 & 100.0 \\
\hline $\begin{array}{l}\text { Pernah atau } \\
\text { tidak } \\
\text { mendapat } \\
\text { iformasi }\end{array}$ & $\begin{array}{c}\text { Jumlah } \\
\text { (n) }\end{array}$ & $\begin{array}{c}\text { Persentase } \\
(\%)\end{array}$ \\
\hline Pernah & 62 & 79.5 \\
\hline Tidak & 16 & 20.5 \\
\hline Jumlah & 78 & 100.0 \\
\hline $\begin{array}{l}\text { Sumber } \\
\text { Informasi }\end{array}$ & $\begin{array}{c}\text { Jumlah } \\
\text { (n) }\end{array}$ & $\begin{array}{c}\text { Persentase } \\
(\%)\end{array}$ \\
\hline Nakes & 28 & 45 \\
\hline $\begin{array}{l}\text { Media } \\
\text { elektronik }\end{array}$ & 13 & 21 \\
\hline Media masa & 13 & 21 \\
\hline Orang lain & 8 & 13 \\
\hline Jumlah & 62 & 100.0 \\
\hline
\end{tabular}

Berdasarkan tabel 5.1 diketahui bahwa dari 78 responden 40 responden $(51.3 \%)$ berumur 41-60 tahun, 42 responden (53.8 $\%$ ) bekerja sebagai petani, 36 responden (46.2\%) berpendidikan SD, 44 responden
(56.4\%) mempunyai penghasilan kurang dari 1 juta, 62 responden $(79.5 \%)$ pernah mendapatkan informasi tentang BPJS dan dari 62 orang informasi tersebut 28 responden $(45 \%)$ didapatkan dari tenaga kesehatan

\section{Deskripsi Data Variabel Penelitian}

Tabel 5.2 Deskripsi data variable penelitian pengetahuan tentang BPJS dan perilaku responden dalam mengikuti program BPJS

\begin{tabular}{lcc}
\hline Pengetahuan & $\begin{array}{c}\text { Jumlah } \\
(\mathbf{n})\end{array}$ & $\begin{array}{c}\text { Persentase } \\
(\boldsymbol{\%})\end{array}$ \\
\hline Baik & 23 & 29.5 \\
Cukup & 22 & 28.2 \\
Kurang & 33 & 42.3 \\
Jumlah & 78 & 100.0 \\
\hline$\quad$ Perilaku & & \\
$\quad$ dalam & Jumlah & Persentase \\
$\quad$ mengikuti & $(\mathbf{n})$ & $(\boldsymbol{\%})$ \\
$\quad$ program & & \\
$\quad$ BPJS & & 35.9 \\
\hline mengikuti & 28 & \\
Tidak & & 64.1 \\
mengikuti & 50 & 100 \\
Jumlah & 78 & \\
\hline
\end{tabular}

Berdasarkan tabel 5.2 diketahui bahwa dari 78 responden 33 responden $(42.3 \%)$ mempunyai pengetahuan kurang, dan 54 responden $(69.2 \%)$ tidak mengikuti program BPJS.

Analisis Bivariat Untuk analisis bivariat pada penelitian ini digunakan uji ChiSquare dengan tujuan mengetahui hubungan antara pengetahuan responden tentang BPJS dengan perilaku responden dalam mengikuti program BPJS

Tabel 5.3 Tabulasi silang antara pengetahuan responden dengan peilaku responden dalam mengikuti program BPJS dan hasil uji Chi-Square

\begin{tabular}{|c|c|c|c|c|c|c|c|}
\hline & & & $\begin{array}{l}\text { ku re } \\
\text { gikuti }\end{array}$ & $\begin{array}{l}\text { nden } \\
\text { ggran }\end{array}$ & $\begin{array}{l}\text { alam } \\
\text { 3PJS }\end{array}$ & & \\
\hline & & ya & $\%$ & $\begin{array}{c}\text { ti- } \\
\text { dak }\end{array}$ & $\%$ & $\begin{array}{l}\text { To } \\
\text { tal }\end{array}$ & $\%$ \\
\hline & B & 14 & 60.9 & 9 & 39.1 & 23 & 100 \\
\hline & C & 7 & 31.8 & 15 & 68.2 & 22 & 100 \\
\hline 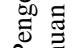 & K & 7 & 21.2 & 26 & 78.8 & 33 & 100 \\
\hline
\end{tabular}

Berdasarkan tabel 5.3 diketahui bahwa responden yang mempunyai pengetahuan 
baik 14 responden (60.9\%) mengikuti program BPJS dan Dilihat dari nilai $\mathrm{p}$ sebesar 0.009 artinya ada hubungan antara pengetahuan responden tentang BPJS dengan perilaku responden dalam mengikuti program BPJS

\section{Pembahasan}

Pengetahuan merupakan hasil "tahu" dan ini terjadi setelah orang melakukan penginderaan terhadap suatu objek tertentu termasuk yang berkaitan dengan BPJS. Dalam hal ini seseorang dapat mengetahui tentang BPJS kesehatan di karenakan orang tersebut pernah mendengar informasi tentang BPJS, melihat pelayanan BPJS ataupun merasakan bagaimana pelayanan kesehatan bila mengikuti program BPJS. Berdasarkan tabel 5.2 bahwa pengetahuan responden tentang BPJS dari 78 responden 33 responden $(42.3 \%)$ mempunyai pengetahuan kurang. Pengetahuan dapat dipengaruhi oleh beberapa faktor baik internal misalnya usia, intelegensi dan faktor eksternal misalnya pendidikan, pekerjaan, informasi, lingkungan, pengalaman, sosial budaya. Usia mempengaruhi terhadap daya tangkap dan pola pikir seseorang. Semakin bertambah usia akan semakin berkembang pula daya tangkap dan pola pikirnya, sehingga pengetahuan yang diperolehnya semakin membaik. Berdasarkan tabel 5.1 diketahui bahwa dari 78 responden 40 responden $(51.3 \%)$ berumur 41-60 tahun. Ditinjau dari dimensi psikologis usia tersebut termasuk dalam usia dewasa akhir (late adults) pada masa ini sebenarnya kematangan sudah terbentuk dan salah satu ciri dari kematangan tersebut adalah setiap keputusan yang diambilnya berdasarkan pandangan yang objektif (Ali, 2007). Namun disisi lain kita tidak dapat mengajarkan kepandaian baru kepada orang yang sudah tua karena mengalami kemunduran baik fisik maupun mental. Dapat diperkirakan bahwa IQ akan menurun sejalan dengan bertambahnya usia, khususnya pada beberapa kemampuan yang lain seperti misalnya kosakata dan pengetahuan umum. Beberapa teori berpendapat ternyata IQ seseorang akan menurun cukup cepat sejalan dengan bertambahnya usia. Hal ini menyebabkan walaupun dari 78 responden 62 responden $(79.5 \%)$ pernah mendapatkan informasi tentang BPJS dan dari 62 responden 28 responden (45\%) mendapatkan informasi tersebut dari tenaga kesehatan tetapi informasi tersebut masih sulit untuk dipahami. Apalagi bila dilatarbelakangi dengan mempunyai tingkat pendidikan yang rendah dalam hal ini hanya mampu mengenyam pendidikan SD. Berdasarkan tabel 5.1 diketahui bahwa dari 78 responden 36 responden (46.2 \%) berpendidikan SD. Pendidikan adalah suatu usaha untuk mengembangkan kepribadian dan kemampuan di dalam dan di luar sekolah dan berlangsung seumur hidup. Pendidikan mempengaruhi proses belajar, makin tinggi pendidikan seeorang makin mudah orang tersebut untuk menerima informasi. Dengan berpendidikan SD maka seseorang akan cenderung mendapatkan informasi yang sangat terbatas dari pendidikan formal termasuk informasi mengenai kesehatan dan BPJS. Semakin sedikit informasi yang masuk maka semakin sedikit pula pengetahuannya. Pengetahuan atau kognitif merupakan domain yang sangat penting untuk terbentukanya tindakan seseorang (over behavior) dari pengalaman dan penelitian terbukti bahwa perilaku yang di dasari oleh pengetahuan akan lebih langgeng dari pada perilaku yang tidak di dasari oleh pengetahuan (Sunaryo, 2004). Perilaku kesehatan adalah suatu respon seseorang (organisme) terhadap stimulus atau objek yang berhubungan dengan sakit dan penyakit, sistem pelayanan kesehatan, makanan dan minuman serta lingkungan (Maulana, 2009). Termasuk dalam hal ini adalah perilaku dalam mengikuti program BPJS. Berdasrkan tabel 5.2 diketahui 
bahwa dari 78 responden 54 responden $(69.2 \%$ ) tidak mengikuti program BPJS.

Program BPJS merupakan jaminan kesehatan sosial yang wajib diikuti oleh masyarakat yang ada di Indonesia. Dalam bidang kesehatan BPJS merupakan program baru untuk menjamin bahwa masyarakat dapat memperoleh pelayanan kesehatan yang aman, bermutu, dan terjangkau. Berhubung program baru maka hal ini merupakan perilaku baru yang harus diikuti oleh masyarakat. Perubahan atau adopsi perilaku baru yang terjadi secara berurutan mengikuti tahaptahap domain kognitif, afektif dan psikomotor (K-A-P) (Maulana, 2009). Berdasarkan tabel 5.3 diketahui bahwa responden yang mempunyai pengetahuan baik 14 responden $(60.9 \%)$ mengikuti program BPJS, yang mempunyai pengetahuan kurang 26 responden $(78.8$ $\%)$ tidak mengikuti program BPJS dan dilihat dari nilai p sebesar 0.009 artinya ada hubungan antara pengetahuan responden tentang BPJS dengan perilaku responden dalam mengikuti program BPJS. Kondisi ini sesuai dengan teori di atas dan sejalan dengan teori dari Lawrence Green (1980) yang menyatakan bahwa salah satu faktor yang mempengaruhi perilaku adalah faktor faktor predisposisi (predisposing factor) yaitu faktor yang mempermudah terjadinya perilaku seseorang misalnya pengetahuan. Responden yang mempunyai pengetahuan baik tentang BPJS akan mempunyai perilaku positif terhadap kesehatan dengan cara mengikuti program BPJS. Hal ini dikarenakan responden telah memahami manfaat bila mengikuti dan kerugian bila tidak mengikuti program BPJS. Begitu pula sebaliknya bagi responden yang mempunyai pengetahuan kurang tentang BPJS maka tidak mempunyai dasar yang kuat untuk membuat perilaku baru dan cenderung tidak mengikuti perilaku baru tersebut atau dalam hal ini tidak mengikuti program BPJS. Selain itu perilaku juga dapat dipengaruhi oleh faktor pendorong (enabling factor) yaitu faktor yang memungkinkan terjadinya perilaku. Misalnya lingkungan fisik, sarana kesehatan atau sumber-sumber khusus yang mendukung dan keterjangkauan sumber atau fasilitas kesehatan (Maulana, 2009). Penghasilan merupakan salah satu contoh sumber-sumber khusus yang mendukung dan keterjangkauan sumber atau fasilitas kesehatan. Berdasarkan tabel 5.1 diketahui bahwa dari 78 responden 44 responden (56.4 \%) mempunyai penghasilan kurang dari 1 juta. Dengan penghasilan yang sangat minim membuat orang berpikir dua kali untuk mengikuti program BPJS karena harus mengangsur setiap bulannya, apalagi bila ditambah dengan kurangnya pengetahuan tentang BPJS maka hal ini dapat membuat responden lebih memilih tidak mengikuti program BPJS.

\section{SIMPULAN}

Ada hubungan antara pengetahuan responden tentang BPJS dengan perilaku responden dalam mengikuti program BPJS di RT 001 RW 001 desa Tenggarejo Kecamatan Tanggunggunung Kabupaten Tulungagung

\section{DAFTAR PUSTAKA}

Ali, M. (2007). Ilmu dan Aplikasi Pendidikan. Jakarta: IMTIMA.

Depkes, RI. (2008). Pedoman Pelaksanaan Sistem Jaminan Masyarakat. Jakarta: Departemen Kesehatan RI

(2011). Statistik Sistem

Jaminan Sosial. Retrieved oktober 24, 2014, from http://www.ppjk.depkes.go.id. (2013). Buku Pegangan Sosialisasi Jaminan Kesehatan Nasional Dalam Sistem Jaminan Sosial. Jakarta: Kemenkes RI. (2014). Buku Panduan Layanan Bagi Peserta BPJS Kesehatan. Retrieved Oktober 24, 2014, from http://sappk.itb.ac.id. 
ISSN Cetak 2303-1433

ISSN Online: 2579-7301

Maulana, H. D. (2009). Promosin Kesehatan. Jakarta: EGC.

Notoatmodjo, S. (2003). Ilmu Kesehatan Masayarakat. Jakarta: Rineka Cipta.

Sunaryo. (2004). Psikologi untuk keperawatan. Jakarta: EGC.

Setiadi. (2007). Konsep Dan Penulisan Riset Keperawatan . Yogyakarta: Graha Ilmu.
Taher, M. (2013). Urgensi Taksonomi Bloom Domain Kognitif Versi Baru dalam Kurikulum 2013. Medan: Balai Diklat Keagamaan Medan.

Yustisia. (2014). Panduan Resmi Memperoleh Jaminan Kesehatan dari BPJS . Jakarta: Visimedia. 